\title{
Empirically Testing the Public Value Based Conceptual Framework for Evaluating E-Government Performance in Vietnam
}

\author{
Thai Thanh Ha \\ Department for Academic Affairs, National Academy of Public Administration, Hanoi City, Vietnam \\ Email: thaiha63@yahoo.com
}

Received 8 January 2016; accepted 16 February 2016; published 19 February 2016

Copyright (C) 2016 by author and Scientific Research Publishing Inc. This work is licensed under the Creative Commons Attribution International License (CC BY). http://creativecommons.org/licenses/by/4.0/ c) (i) Dpen Access

\begin{abstract}
Very little research has been conducted on the performance of e-Government across countries. They are theoretically focusing on the public value-based conceptual framework, resulting in the lack of empirical evidence on its validity. As for Vietnam, evaluating the e-Government performance is still new, not to mention being absent in the literature. Therefore, an empirical test of the public value-based conceptual framework was needed for evaluation of e-Government performance in Vietnam. Firstly, the research went through the review of the literature on e-Government as well as public service delivery related issues. Secondly, it operationalized the items on the basis of revised public value-based e-Government performance conceptual framework. Thirdly, the field survey was carried out using self-administered questionnaires with appropriate sampling structure. Finally, data analysis was performed and interpreted. Recommendations were drawn for proposed and revised conceptual framework for future research in Vietnam.
\end{abstract}

\section{Keywords}

Public Value, E-Government Performance, Vietnam

\section{Introduction}

Public value is what citizens seek from public services and from the achievement of socially desirable strategic outcomes [1]. In the mean time, electronic government, notably e-Government for short, refers to "the utilization of IT, ICTs, and other web-based telecommunication technologies to improve and enhance the efficiency and effectiveness of service delivery in the public sector" [2] [3]. As a result tremendous investment has been made in implementing diverse e-Government initiatives worldwide [4]. In this context evaluating the performance of 
e-Government has become urgent [5] [6]. To date, there has been a scattered proportion of research conducted either from the perspective of e-Government service performance such as reducing operating costs, enhancing the administrative ability [7] or on the ground of citizen's involvement namely the trust towards the government affairs and its accountability [8]. A holistic model to bring about a convergence of both as an integrated whole is needed more than ever, especially in the context of developing countries [6] [7] [9].

In this paper we adopted and operationalized the constructs which are theoretically based on the conceptual framework as suggested by Karunasena and Deng [10] and further revised by Bai [6]. We went further by empirically testing the validity of the proposed model with the use of exploratory factor analysis in an attempt to identify the dimensions influencing the public value-based performance of e-Government. On the basis of the findings, a revised conceptual framework is suggested for evaluating the performance of e-Government in Vietnam.

\section{E-Government Development in Vietnam}

According to a joint survey by UNDESA [11], with an exception of Singapore, the rest of ASEAN's e-Government development is still in its initial stages with regards to public administration reform, infrastructure, and broadband access. Furthermore, ASEAN member nations have developed unevenly with Singapore taking the first place while Cambodia is still at the bottom of the ranking. Table 1 shows that it has been still stuck in the middle group. Yet, Vietnam is setting a target of pursuing an ambitious take-off ITC development strategy with which Vietnam would jump ahead of the rest of ASEAN countries in terms of e-Government development [12].

World Economic Forum conducting series of reports concerning the networked readiness index for 148 countries also confirmed the stagnation for Vietnam over the past four years. Table 2 shows Vietnam's composite networked readiness index which has no improvement with regards to the rank and score. In 2012 it was ranked as 83 instead of 85 in 2015. Apart from the impact index which shows an upward trajectory from respective rankings of 79 in 2012 and 71 in 2015, Vietnam seemed to undergo a degradation in terms of environment, readiness and usage indexes [13]-[16].

The Vietnamese government, recognizing the potential of ICT as an enabling tool for public service delivery and as a potential source of economic growth [17], has turn the development of this sector into a national priority. The Vietnamese government has specifically laid concrete regulations which are concerned with the expansion of the networking of the e-Government from the central level down to the local grassroots [18]-[20]. These decrees have been issued in an attempt to smooth out the e-Government process, and thus, lay a sound foundation for better e-Government performance on a nation-wide scale. According to World Bank [21] Vietnamese government services has been improved with e-applications contributing to a reduction in turn-around for gov-

Table 1. Vietnam's e-Government index as compared to ASEAN.

\begin{tabular}{ccccccc}
\hline $\begin{array}{c}\text { ASEAN } \\
\text { Country }\end{array}$ & $\begin{array}{c}\text { E-Government } \\
\text { Rank }\end{array}$ & $\begin{array}{c}\text { E-Government } \\
\text { Index }\end{array}$ & $\begin{array}{c}\text { E-Participation } \\
\text { Index }\end{array}$ & $\begin{array}{c}\text { On-Line Service } \\
\text { Index }\end{array}$ & $\begin{array}{c}\text { Human Capital } \\
\text { Index }\end{array}$ & $\begin{array}{c}\text { Telecom Infrastructure } \\
\text { Index }\end{array}$ \\
\hline Singapore & 3 & 0.9 & 0.9 & 0.99 & 0.85 & 0.87 \\
Malaysia & 52 & 0.61 & 0.52 & 0.67 & 0.71 & 0.44 \\
Brunei & 86 & 0.5 & 0.05 & 0.36 & 0.78 & 0.36 \\
\hline & & & Middle Group & & 0.24 \\
Philippines & 95 & 0.47 & 0.56 & 0.48 & 0.7 & 0.37 \\
Vietnam & 99 & 0.47 & 0.49 & 0.41 & 0.61 & 0.28 \\
Thailand & 102 & 0.46 & 0.54 & 0.44 & 0.66 & 0.3 \\
Indonesia & 106 & 0.44 & 0.29 & 0.36 & 0.67 & 0.2 \\
\hline Cambodia & 139 & 0.29 & Lower Group & & 0.16 \\
Laos PDR & 152 & 0.26 & 0.19 & 0.19 & 0.14 & 0.49 \\
Myanmar & 175 & 0.18 & 0.07 & 0.02 & 0.52 & 0.01 \\
\hline
\end{tabular}

Sources: UNDESA [11]. 
Table 2. Vietnam’s ITC rankings for 2012-2015 period.

\begin{tabular}{cccccccccc}
\hline \multirow{2}{*}{ Vietnam's ITC Indexes } & \multicolumn{2}{c}{2012} & \multicolumn{2}{c}{2013} & \multicolumn{2}{c}{2014} & \multicolumn{2}{c}{2015} \\
\cline { 2 - 9 } & Rank & Score & Rank & Score & Rank & Score & Rank & Score \\
\hline Environment Index & 83 & 3.7 & 97 & 3.6 & 96 & 3.7 & 98 & 3.6 \\
Readiness Index & 96 & 3.6 & 79 & 4.4 & 77 & 4.7 & 84 & 4.5 \\
Usage Index & 69 & 3.5 & 73 & 3.5 & 78 & 3.6 & 82 & 3.6 \\
Impact Index & 79 & 3.3 & 75 & 3.4 & 75 & 3.4 & 71 & 3.6 \\
Composite Networked Readiness Index & 83 & 3.7 & 84 & 3.7 & 84 & 3.8 & 85 & 3.9 \\
\hline
\end{tabular}

Source: World Economic Forum [13]-[16].

ernment services. For example, time to approve procurement contract in Danang, Hanoi and Ho Chi Minh city has been reduced from 4 - 5 months to 90 days.

Danang has been considered as the pioneer city considering the e-Government services as a fastest way to turn it into what is labeled "smart city". According to VCCI [22] the adoption of Danang's e-Government strategy is aimed at the tasks to be achieved as follows: 1) Full-fledged ITC application in public services organizations; 2) Capable human resource development especially in the field of ITC; 3) Perfection of institutional set-up for ITC development; 4) Development of competitive ITC industry; 5) Laying solid ground for ITC infrastructure; 6) long-term visionary development of ITC foundation technology; 7) Raising ITC awareness and culture. Vietnam Chamber of Commerce and Industry (VCCI) also listed a number of 1196 types of second-level on-line public services and 498 types of third and fourth level on-line public services for the citizens and businesses. It is worth noticing that the Ministry of Information and Telecommunication planned to replicate the ITC model of Danang on a nation-wide scale. However, with more than 80 percent of population in rural areas, the success of this expansion is still questionable [22] [23].

\section{Literature Review}

So far, there have been a very few studies on evaluating performance of e-Government [24]. It is a new field of research in Vietnam as the case in point. The literature shows that these e-Government studies, even though sharing the same concept of public value, yet they have the advantages and limitations of their own. They do not generate an all-rounded and comprehensive conceptual framework on the ground of public value-based eGovernment performance. Furthermore, these studies are disproportionately scattered on the perspective of either citizen or the side of government. From the view point of citizen, there have been serious efforts in trying to conceptualize the citizen's trust in e-Government with the application of Q-Methodology [8]. It is concluded that 77-item constructs confirmed the validity and reliability and can be used for large-scale citizen's trust in e-Government. There has been an indication that the e-Government affairs are demanded to coordinate and formulate the relationships of means and ends between e-Government affairs and popular culture service [25].

The concept of public value is increasingly becoming an innovative driver in modern e-Government endeavors [26] [27]. Castelnovo and Simonetta [28] while reasoning that public administration aims at producing value for citizens, concluded that the use of ICT can be used as an effective way of improving the public value. In other words the government makes the use of ICT to enhance its own capacity to deliver what people want, and eventually a public value is created [29] [30].

It is stated that e-Government has considerable potential to contribute to efficiency gains and cost reductions for businesses and private organizations [31]. Furthermore, these benefits constitute a major aspect of e-Government initiatives. Putting services on-line substantially decreases the processing costs of many activities compared with the manual way of handling operations. For example, it costs the US Inland Revenue Service \$1.60 to process a paper tax form, but only $\$ 0.40$ to process an electronic form [31]. However, there are several non-monetary benefits associated with the e-Government performance. This must be taken into consideration and that neglecting these can give rise to major limitations to the process of evaluating e-Government performance [6]. The European Commission proposes a conceptual framework for examining different types of values of e-Government [7]. The public value of e-Government initiatives are investigated from the perspectives of 1) organizational value; 2) political value; and 3) user value. The organizational value concerns the operations efficiency and effectiveness of public organizations [10]. The political value relates to the openness and transparency of the pub- 
lic sector and the participation of citizens in government affairs. The user value focuses on improving the satisfaction of citizens with regard to the delivery of public services. The approach of the European Commission has beeb criticized for failing to include governments' E-enabling of civil society in the evaluation process [9].

Golubeva [32] focuses on the public value created by portals of Russian government, but limitations are that the portals cannot represent the whole e-Government performance. Heeks [9] discusses in more detail the aspects of service, outcomes and trust, but "trust" is also not fully covered and integrated into the e-Government performance as a whole. Kim [33] merely confirms that management for results is the most significant factor affecting the perceived performance of e-Government while ignoring the other factors such as the intra-strategic connections among public organizations. Fan [34] focuses on the evaluation of e-Government development by local authorities in Australia for the reasoning that it is not only essential to improve the effectiveness of local government websites but also to promote greater awareness of the benefits of using e-Government services at the local government setting. However, the limitations rest with the tiny research scope of websites and local government level, leaving the broad range of issues on e-Government performance and public value unanswered. These limitations also coincide with those of the work of Nabafu and Maiga [35] which only identifies the success factors for implementing local e-Government in Uganda, yet neglecting the public service delivery and the achievements of outcomes, and most importantly the privacy and security of e-Government.

In an effort to empower and deliver better public service, it is suggested that e-Government can be implemented in a number of ways in order to accelerate information dissemination, to increase the transparency and accountability for the government administration, to reduce corruption, and to facilitate the citizen's participation in government affairs [1] [2]. This suggestion seems to point out some connections between the government effectiveness and citizen involvement. Yet, the generalization of the public value and e-Government is still naive. Yang [25] indirectly implies that e-Government affairs are demanded to coordinate the service standard of popular culture with the public acceptance rate. It forms the relationships of means and ends between e-Government affairs and popular culture service. However, the concept of public value and its interaction with e-Government performance is still far from reaching.

Bai [6] conducts a thorough review of the public value and how it can be incorporated into the evaluation of e-Government performance for China. The conclusion boils down to the fact that a revised conceptual framework should be derived on the basis of original framework as developed by Deng [24]. It aims to fit into the context of Chinese e-Government status quo and current practices. Namely, public value is composed of three core dimensions in terms of e-Government performance: 1) Delivery of public service which can be operationalized into 6 attributes; 2) Effectiveness of public organization stretching into 3 attributes; 3) Development of trust consisting 4 attributes. In comparison to the original conceptual framework [24], it takes away the e-Government achievement in terms of direct, intermediate and end outcomes [10]. The shortcoming of conceptual framework was merely suggested on the theoretical ground, without any empirical testing to validate the model. It is concluded that advantages and disadvantages of the literature must be take into consideration. Therefore, it is advisable that evaluation perspective should be holistic from both government agencies and citizen sides. That is, the quality of public service and efficiency should be taken into consideration as well as citizen satisfaction and trust toward e-Government should be covered [36].

\section{Proposed Conceptual Framework}

Given the typical political and social characteristics of the country, Vietnam's e-Government services has embarked on a unique path with a large proportion of population living in rural areas and average score and ranking of networked readiness [11]. Considering the implications from literature review on the evaluation of e-Government public value, we adopted the original conceptual framework as developed by Karunasena and Deng [10] and revised it by adding some substances to the construct of effectiveness of public organization as presented in Figure 1.

Specifically, they are the reductions in costs or expenses among the departments of public organization when one-stop shop formality is put in place. This type of cost cutting is different from cost-savings elaborated from the citizens' side as it is mentioned in the construct of public service delivery [10]. E-Government must be used to improve the public services by cutting processing cost, managing performance, and making strategic connections between and among government agencies [9]. These activities all can save public money. In this context, the efficiency of public organization is determined by the financial return of investment [37]. 


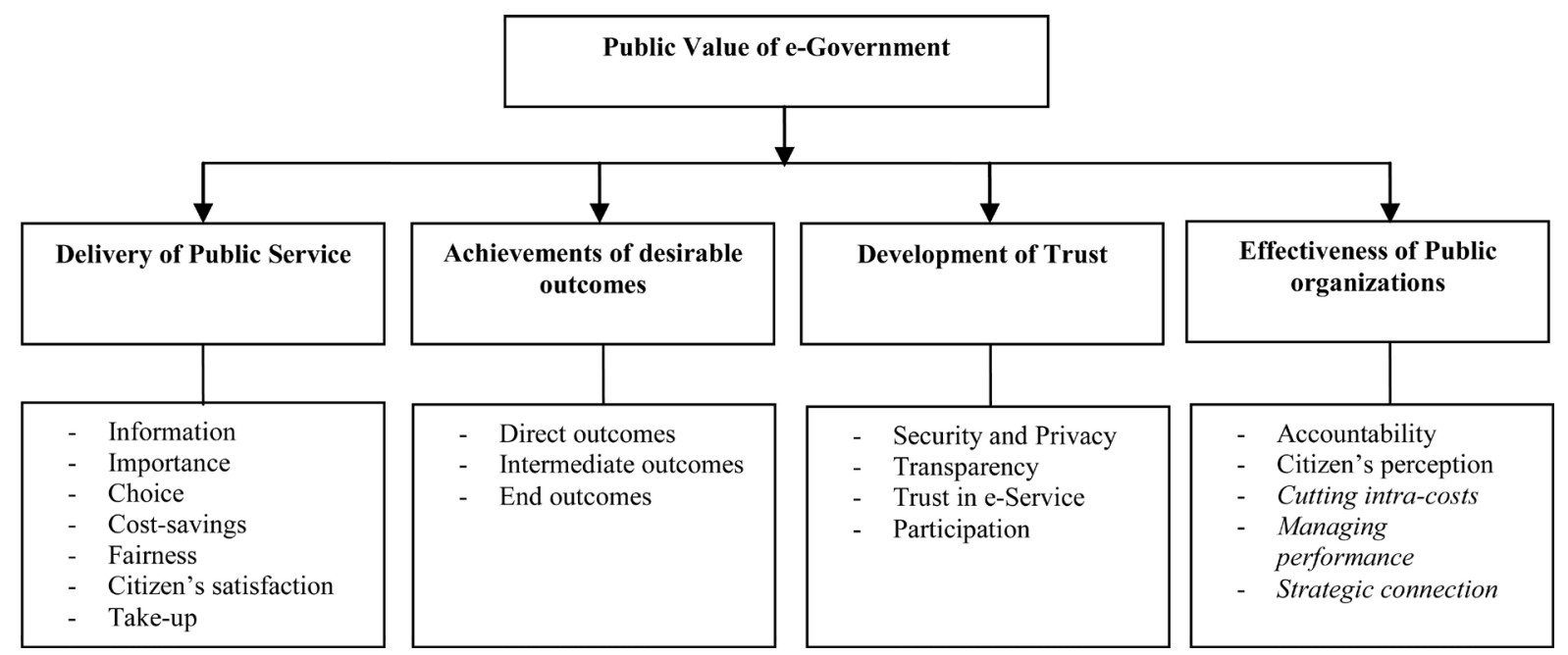

Source: Author's adaptation from Karunasena and Deng [10] and Bai [3].

Figure 1. Proposed conceptual frame work for the research.

The delivery of public services concerns the quality of the service delivered through e-Government and the timeliness of such deliveries. E-Government's public service delivery is dependent on the availability of information, the importance of information to citizens [38], the variety of choice citizens can take, cost savings, fairness of services, satisfaction of citizens, and take-up of e-Government services [3]. The availability of information concerns about the amount and type of information available to citizens through e-Government services [39].

The importance of information is a reflection of the perception and requirements of citizens with respect to their specific needs [10]. The choice refers to the availability of e-Government service delivery channels to citizens for accessing public services [8]. The cost saving of e-Government relates to the amount of money that citizens can actually save through e-Government service compared to traditional government services. The fairness of e-Government services delivery refers to the extent to which e-Government services are available to the whole population including socially disadvantaged groups. This is reflected through the availability of resources for disadvantaged groups to access e-Government services among all walks of life [40]. The satisfaction of citizens with e-Government services is reflected through the experience of citizens in using e-Government services [41]. The take-up of e-Government is measured by the number of users who have used at least one e-Government service [26].

Achieving socially desirable outcomes is a major source of public value creation through e-Government. It is reflected by the impact, deliverables, and consequences that public services are designed to attain [42]. Outcomes include initial outcomes, intermediate outcomes, and long term outcomes and can also be classified as direct outcomes, intermediate outcomes, and end outcomes [43]. In general, achieving intended results for specific constituencies are direct outcomes, producing results for entire sectors are intermediate outcomes, and achieving specific targets for the entire society or economy are end outcomes [10].

The development of trust between citizens and government is the third dimension for examining the public value of e-Government [41]. It can be assessed from the perspectives of a) security and privacy of citizens' information [3]; b) transparency of e-Government services [44]; c) trust of citizens in e-Government services [3]-[8]; and d) participation of citizens in public discussions [40]. The security and privacy of citizens' information in using e-Government services refers to the extent to which the government securely manages citizens' personal information [8]. This is often reflected by individual organizations' readiness to secure citizens' personal information and development of effective law and regulations with respect to the use of e-Government [44]. The transparency of e-Government refers to the extent to which an organization reveals work, processes and procedures [38]. A transparent government discloses its performance information timely. The public trust in e-Government services is measured by the citizens' perceptions about the e-Government services delivered by the public organization [8]. The participation of citizens in government affairs can take the forms through the active involvement of citizens in the public decision making process, online consultation services with the use of 
web tools such as online forums, blogs, community networks, and newsgroups [10]-[12] [17]-[21] [23]-[36] [45].

The effectiveness of public organizations is a key indication of public value created through e-Government [37]. This is measured by efficiency, accountability, and citizens' perceptions about public organizations [10]-[12] [17]-[21] [23]-[46]. Accountability refers to the "answerability of government to public on its performance" [3] [47]. In e-Government, accountability is reflected by the number of public agencies publishing online full organizational charts and the contact information [48]. The perceptions of citizens' on a public organization where e-Government initiatives are implemented are found by the number of citizens who have positive or negative opinion about the e-enabled public organizations [49].

\section{Research Methods}

\subsection{Measurements}

In this research the constructs are theoretically based on the comprehensive review of the literature and grounded on the proposed conceptual framework to avail themselves of the advantage of validity of existing research [50], and to take into consideration of the country's e-Government status quo [6]. Compared to the original conceptual framework as developed by Karunasena and Deng [10] which consists of 17 items, our research has more added value. Practically these original 17 item do not fully cover the effectiveness of e-Government services. Therefore, we made an addition of 3 more items to clarify the effectiveness of e-Government services and thus fulfilling the gap in this regard. Namely, 1) cutting the processing intra-costs is an useful aspect for the improvement of public service; 2) the efficiency of e-Government services is well-reflected in making strategic connections between and among government agencies [9]; and 3) as the result, the efficiency of public organizations is determined by the financial return of investment on e-Government services [7] [10]. In short, this reserch's proposed conceptual framework consists of 20 items reflecting four aspects of evaluating public value-based e-Government performance in Vietnam as mentioned in the literature. The items for public value were operationalized on the basis of proposed conceptual framework as shown in Figure 1. These operationalized items would be put into self-administered questionnaires as statements on 5-point Likert scale for data collection.

\subsection{Questionnaire Development and Back-Translation}

To collect the information for analysis, a version of self-administered questionnaire using five-point Likert scale was developed and followed up in the field survey. All of the 20 items were first taken from the proposed conceptual framework as mentioned above, and then developed in English. It was then translated into Vietnamese by a bilingual researcher. A different bilingual counterpart translated the questionnaires back into English. This was done because most of the instrumentation had been designed in the West, and evidence of cross-cultural validity of the variable operationalization was scant [50] [51]. To verify the accuracy and quality of the translations, pre-tests using both the original and translated version was conducted on two bilingual respondents [51]. The results showed that both Vietnamese and English versions of questionnaire produced the same pattern of responses, confirming that the translated questionnaires were sufficiently reliable.

\subsection{Sample and Data Collection}

In Vietnam data collection is very problematic. Researchers usually face a number of obstacles, including the inefficiencies and undependability of the postal system. Therefore, field data collectors were trained to conduct face-to-face interview in which the aim of the research was explained in detail or in case questions may need clarification. Self-administered questionnaires were given to the respondents to fill in. Data were gathered from a number of public officers who were undergoing a short training courses organized by the Ministry of Home Affairs (MOHA) in Central Vietnam. This resulted in 192 completed usable questionnaires which are sufficient to conduct exploratory factor analysis [52].

\section{Data Analysis}

We used IBM Statistics version 19 to perform data inputting, processing and analysis. The demographic characteristics of the sample are presented in Table 3. Total respondents were rather equally distributed in terms of male (60 percent) and female (40 percent) in the sample. The respondents ranged from 30 to 40 years of age, 
Table 3. Demographic characteristics of the sample size.

\begin{tabular}{|c|c|c|c|c|c|}
\hline Gender & $\mathrm{N}$ & $\%$ & Ages & $\mathrm{N}$ & $\%$ \\
\hline Female & 78 & 40.6 & Below 30 & 44 & 23.2 \\
\hline Male & 114 & 59.4 & $30-40$ & 106 & 55.8 \\
\hline Total & 192 & 100 & $40-50$ & 31 & 16.3 \\
\hline Frequency of Using E-Government Services & $\mathrm{N}$ & $\%$ & Above 50 & 9 & 4.7 \\
\hline At Least One Time & 9 & 4.7 & Total & 190 & 100.0 \\
\hline Always Using E-Government Services & 23 & 12.0 & Position & $\mathbf{N}$ & $\%$ \\
\hline Frequently Using E-Government Service & 84 & 44.0 & Manager & 53 & 27.6 \\
\hline Some Time Using E-Government Service & 70 & 36.6 & Specialists & 105 & 54.7 \\
\hline Never Use of E-Government Service & 5 & 2.6 & Others & 34 & 17.7 \\
\hline Total & 191 & 100 & Total & 192 & 100 \\
\hline
\end{tabular}

Source: Data collected from field survey 2015.

with an average of 35. Combined together, the respondents had frequencies of using e-Government services for their routine tasks at least one time, always and frequently, amounting to 97.4 per cent while those who never resorted to the e-Government service occupied just only meager share of 2.6 per cent. More than half of the total respondents fell into the category of being "specialists" ( 55 percent), meaning that they had to get access to e-Government services to perform their jobs on a daily basis. The rest of the respondents were identified as managers or so (46 percent).

Because of a large number of items in the questionnaire exploratory factor analysis with Varimax rotation was used to identify the constructs and to condense the data into confirmed variables. Hair et al. [52] suggests that factor analysis would identify the dimensions of relationship among different items. It can also help researchers create an entirely new set of variables from these items, much smaller in number, to partially or completely replace the original set of variables for inclusion in subsequent analysis. Those dimensions with factor loadings of larger than 0.5 would be considered and retained for the next round of factor analyzing. On the contrary, those items with factor loadings of less than 0.5 should be removed from entering the next round of factor analyzing [50] [52].

To perform this, a sample size must be sufficient when this type of quantitative research is to be carried out. To identify the constructs with items to be highly loaded, Hair et al. [52] suggest that the sample size should be calculated either on the rule-of-thumb condition 5 to 1 or on the condition of statistically significant Kaiser-Meyer-Olkin test known as KMO test for short. For the former condition, that means, each statement items must be backed up by fully filled-in questionnaires. The number of completed self-administered questionnaires amounted to 192 from the field survey which surpassed the sampling requirement.

We ran KMO Barllete test to check the latter condition. Its results also confirmed the sampling adequacy as this procedure was put into use among other researchers [8] [50]. All of the items on the Kolmogorov-Smirnov test for normality indicated the satisfaction of the assumptions for factor analysis. To identify the dimensions which should be used to evaluate e-Government performance based on the public value. We ran exploratory factor analysis in several consecutive rounds to explore until we could identify the hidden dimensions condensed with larger-than- 0.5 factor loadings. After three rounds of factor analyzing, the same number of three constructs were identified with desirable factor loadings of larger than 0.5 . Table 4 presents the findings of exploratory factor analysis and KMO test results in more detail and subsequent description of each round were listed below:

\subsection{First Round of Exploratory Factor Analysis}

The results of the first round of exploratory factor analyzing were presented in second column of Table 4. The Kaiser-Meyer-Olkin (KMO) test for the first round resulted in a value of 0.92. This test value was acceptable and exceeding the level of 0.9 suggested by Hair et al. [52]. In this round such items as Choice and Perception were identified as having factoring loadings of less than 0.5 and should, therefore, be left out of the next round. The reliability tests of Cronbach Alpha reached the levels of 0.878 ; 0.863 and 0.828 which confirmed the validity and reliability of three newly identified constructs. 
Table 4. Exploratory factor analysis to identify valid items to be loaded on dimensions.

\begin{tabular}{|c|c|c|c|c|c|c|c|c|c|}
\hline \multirow{2}{*}{ Items } & \multicolumn{3}{|c|}{ First Round } & \multicolumn{3}{|c|}{ Second Round } & \multicolumn{3}{|c|}{ Third Round } \\
\hline & Factor 1 & Factor 2 & Factor 3 & Factor 1 & Factor 2 & Factor 3 & Factor 1 & Factor 2 & Factor 3 \\
\hline Managing Performance & 0.791 & 0.139 & 0.242 & 0.793 & 0.132 & 0.240 & 0.793 & 0.130 & 0.238 \\
\hline Cutting Intra-Cost & 0.763 & 0.126 & 0.213 & 0.765 & 0.127 & 0.218 & 0.764 & 0.128 & 0.216 \\
\hline Strategic Connection & 0.671 & 0.150 & 0.443 & 0.675 & 0.153 & 0.446 & 0.677 & 0.144 & 0.445 \\
\hline Cost-Savings & 0.661 & 0.248 & 0.149 & 0.661 & 0.223 & 0.145 & 0.661 & 0.223 & 0.147 \\
\hline Financial Return & 0.649 & 0.273 & 0.355 & 0.654 & 0.267 & 0.352 & 0.656 & 0.254 & 0.356 \\
\hline Citizen Participation & 0.614 & 0.471 & 0.001 & 0.626 & 0.483 & -0.007 & 0.624 & 0.491 & 0.005 \\
\hline Importance & 0.610 & 0.178 & 0.213 & 0.612 & 0.172 & 0.220 & 0.622 & 0.133 & 0.226 \\
\hline Take-Up & 0.060 & 0.777 & 0.117 & 0.072 & 0.787 & 0.117 & 0.070 & 0.797 & 0.140 \\
\hline Fairness & 0.385 & 0.716 & 0.065 & 0.185 & 0.718 & 0.303 & 0.392 & 0.717 & 0.085 \\
\hline Direct Outcomes & 0.175 & 0.714 & 0.302 & 0.393 & 0.712 & 0.066 & 0.187 & 0.709 & 0.325 \\
\hline Citizen Satisfaction & 0.326 & 0.655 & 0.218 & 0.335 & 0.651 & 0.219 & 0.336 & 0.643 & 0.236 \\
\hline End Outcomes & 0.080 & 0.619 & 0.583 & 0.092 & 0.631 & 0.586 & 0.093 & 0.625 & 0.604 \\
\hline Information & 0.208 & 0.520 & 0.237 & 0.202 & 0.490 & 0.262 & & & \\
\hline Choice & 0.412 & 0.496 & 0.310 & & & & & & \\
\hline Perception & 0.367 & 0.465 & 0.430 & & & & & & \\
\hline Security and Privacy & 0.153 & 0.204 & 0.742 & 0.155 & 0.199 & 0.747 & 0.160 & 0.173 & 0.752 \\
\hline Accountability & 0.358 & 0.200 & 0.663 & 0.362 & 0.192 & 0.660 & 0.367 & 0.170 & 0.664 \\
\hline Transparency & 0.394 & 0.119 & 0.644 & 0.397 & 0.114 & 0.645 & 0.399 & 0.102 & 0.646 \\
\hline Trust & 0.333 & 0.265 & 0.617 & 0.341 & 0.264 & 0.608 & 0.342 & 0.256 & 0.614 \\
\hline Intermediate Outcomes & 0.115 & 0.596 & 0.613 & 0.123 & 0.597 & 0.615 & 0.128 & 0.576 & 0.633 \\
\hline Cronbach Alpha Reliability & 0.878 & 0.863 & 0.828 & 0.876 & 0.863 & 0.828 & 0.876 & 0.863 & 0.828 \\
\hline Cumulative Variance & $45 \%$ & $53 \%$ & $59 \%$ & $45 \%$ & $54 \%$ & $61 \%$ & $46 \%$ & $55 \%$ & $62 \%$ \\
\hline KMO Measures of Sampling Adequacy & & $0.92^{* * *}$ & & & $0.911^{* * *}$ & & & $0.91^{* * *}$ & \\
\hline
\end{tabular}

Source: Processing of data collected from field survey 2015.

\subsection{Second Round of Exploratory Factor Analysis}

With such items of Choice and Perception to be wiped out, the second round of exploratory factor analyzing continued to be adopted. It also indicated the Kaiser-Meyer-Olkin (KMO) test resulted in a value of 0.911 which is a little lower than that of the first round. However, this test value was still larger than the level of 0.9, thus, confirming the sampling adequacy for factor analysis. In this round, one more item named as Information was identified as having factoring loadings of less than 0.5 . This very item should be left out in the subsequent round of factor analyzing. The reliability tests of Cronbach Alpha reached the level of $0.876 ; 0.843$ and 0.828 which decreased a little as opposed to those of the previous round. However, these reliability test values still confirmed the validity and reliability of these three newly identified constructs.

\subsection{Third Round of Exploratory Factor Analysis}

When three low-factor loadings items of Information, Choice and Perception to be left out, the third round of factor analyzing was undertaken. The results showed that the Kaiser-Meyer-Olkin (KMO) test resulted in a value of 0.910 which remained almost the same at the level of the second round and still larger than the level of 0.9 suggested by Hair et al. [52]. This KOM test result of the third round confirmed again the sampling adequacy for factor analysis. In this third round, all 17 remaining items were highly loaded on the three identified dimension. The reliability tests of Cronbach Alpha reached the level of 0.876; 0.843 and 0.828 which stay constant as compare to those of the second round. these reliability test values once again confirmed the validity and reliability of newly three identified constructs. We halted factor analyzing at the third round because all the loadings 
reached desirable requirements [52].

\subsection{Naming the Newly Identified Dimensions}

As the result of the exploratory factor analysis described from above, Factor 1 is labeled as Effectiveness. It measures the extent to which e-Government performance is a key indication of public value created through e-Government services [10]. It can be evaluated on the basis of managing the performance between or among the government agencies, cutting the processing internal-costs or the external costs to be born by citizens. The two other items such as citizen participation and the importance attaining to the public service delivery are highly loaded on Factor 1. However, the large value related to this new factor item indicates that public value is strongly accrued to the effectiveness of the public organization in terms of managing the performance between and among government agencies [53].

By the same token, Factor 2 was labeled as Public Service Delivery. It measures the extent to which this newly created dimension is concerned with the quality of the service delivered through e-Government and the punctuality of such deliveries. It also takes into account the fairness to treat underprivileged and marginalized citizens on an equal basis [53]. Citizen satisfaction was also highly loaded on Factor 2 because of the loading coefficient exceeding the require level of larger than 0.5 [52]. It is worth of mentioning that two other items (i.e. Direct outcomes and End outcomes) which were described in the proposed conceptual framework were loaded on Factor 2. However, these would not affect the nature of this newly identified factor as the largest loading of item which is managing performance explicitly expresses the label of Factor 2 [44] [46]-[50].

The same reasoning also leads to Factor 3 which is labeled as Trust and Transparency. We combined "Trust" and "Transparency" to create the new factor. This is because "Trust" is the notion that belongs to the citizen's perspective while "Transparency" attains to the government's side (Bai 2013). Therefore, the combination of these two would bring about a holistic dimension as compared to that of the original conceptual frame work known as Development of Trust [10]. All of these items were highly loaded on Factor 3. The item named as Security and Privacy has the largest loading coefficient of 0.66 , followed by such items as "Accountability" (0.645), "Transparency" (0.608), and "Trust" (0.615). The item "Intermediate Outcomes" was also highly loaded on Factor 3. However, this would not affect the nature of Factor 3 which was labeled as Trust and Transparency. How these three newly created dimensions can be integrated in to the proposed conceptual framework is discussed in the next section in more detail.

\section{Discussion of the Findings}

Vietnam is transforming into a networked society where more people are becoming connected, and more advanced applications, such as e-Government, are becoming available [11]. In the course of integrating into global economy, the building of the effective e-Government would help facilitate its capacity to manage resources, implement sound policies and better satisfy the need of its citizens [23]. Therefore, it would be timely to set some light on the public value and how to use it for evaluating the e-Government service performance because of its comprehensiveness.

The empirical test of the data pointed out the constructs for evaluating public value-based e-Government performance. The results confirmed three dimensions that create sources of public value through e-Government performance in a Vietnamese setting. That is, they are: Effectiveness of public organizations; Public service delivery; and Trust and transparency. These three dimensions constitute the proposed conceptual framework for evaluating Vietnam's e-Government performance as presented in Figure 2.

To some extent, these three dimensions are similar to what Bai [6] proposed in the conceptual framework for evaluating public value-based e-Government performance in China because of the "Achievement" dimension to be taken away from both models while "Effectiveness" of public organizations; "Public service delivery"; "Trust and Transparency" stay remained on both conceptual frameworks. The sole difference is that while Bai [6] proposed a conceptual framework for evaluating China's e-Government performance on the basis of public value mostly from the synthesis of literature review and without any empirically testing, the conceptual framework we are proposing for Vietnam's e-Government is more far-reaching due to the fact that it has been built upon both subordinate elements taken from the literature as well as the results of empirically tested data in order to confirm its validity.

Khuong [17], while examining the ITC as the source of economic growth, also confirmed that Internet pene- 


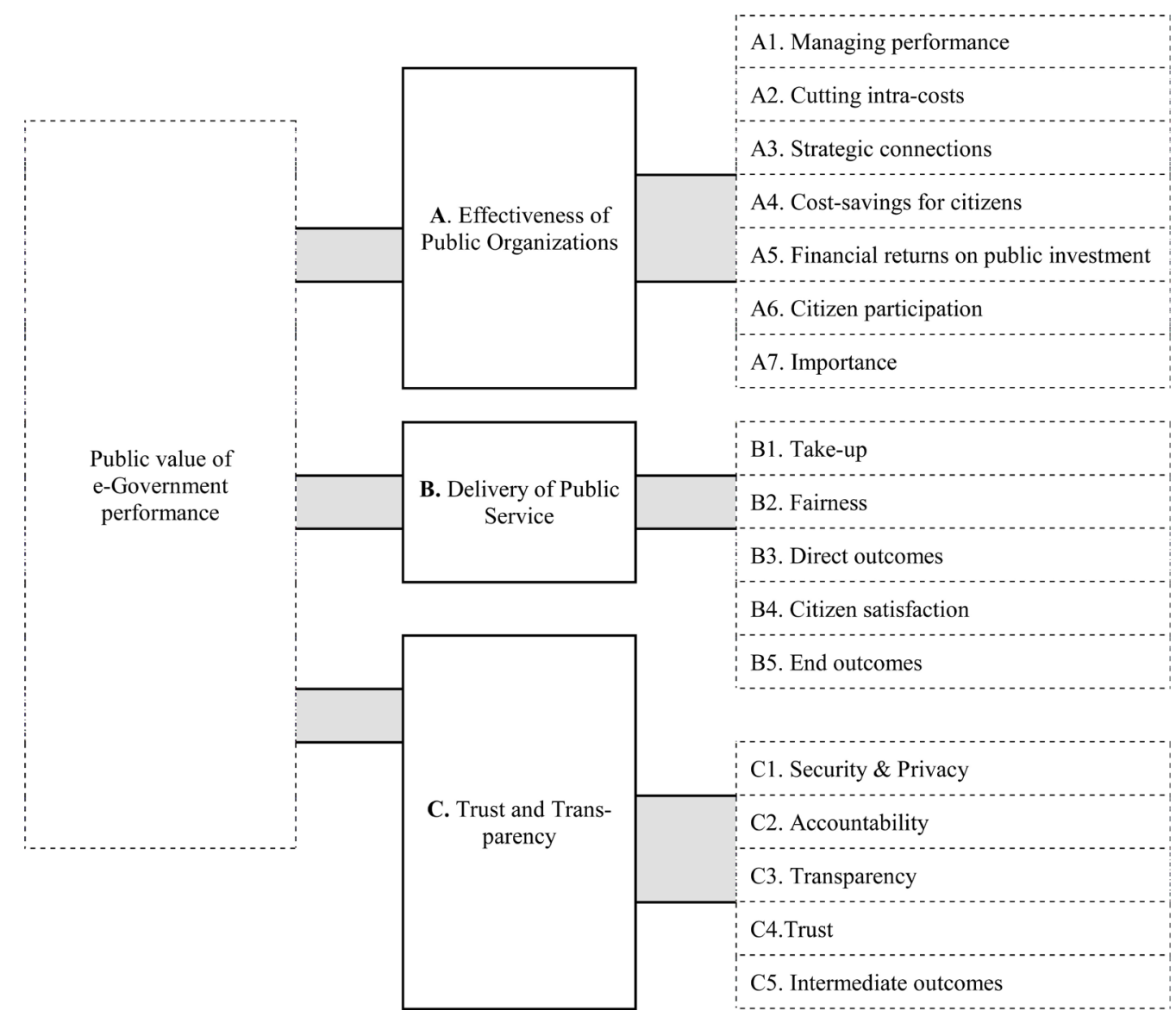

Figure 2. Summary of empirical test of conceptual framework for Vietnam.

tration enhances the quality of decision-making process, which improves the efficiency and effectiveness of resource allocations. That is the reason to indirectly explain the effectiveness of public organizations which plays as an important element in using the E-government to enhance the Vietnamese business competitiveness [22] [54]. The effectiveness of e-Government services provided by public organizations is very clear in Vietnam. On the one hand, it can facilitate the interactive communication to smooth out any administrative problems. On the other hand, e-Government would connect together the government agencies to speed up the processing time. For instance, on-line public services rapidly boosted administrative reform in Quang Ninh province, and quicker administrative procedures develop in many agencies [55]. People and businesses only wait a day or an hour instead of three or four days in previous years [22]. Although there has not been concrete information on financial return on e-Government investment in Vietnam, the positive sign is that the Vietnamese government has appointed a high-ranking Council of Informatics Officers (CIO) to oversee the e-Government investment strategy among its ministries, governmental organizations, and inter-governmental departments. This arrangement is aimed at ensuring the financial efficiency in this regard [18].

Public service delivery is another important dimension that can be found in the proposed conceptual framework for the assessment of Vietnam's e-Government services. On-line electronic services run by the public service departments are expected to provide 60 per cent satisfaction by the end of next year and 80 per cent by the year 2020 [55]. The city of Danang had accelerated administrative reform by putting public services on-line, from 10 services for city agencies to 489. It is aiming to apply more digital procedures to 1,200 public services for the city's 56 communes, precincts and departments [22]. In Vietnam, 100\% provincial authorities have on-line websites where 99,883 first-level on-line public services were provided to citizens in 2012, meaning an increase by approximately $89 \%$ as compared to that of 2008. Hanoi and Ho Chi Minh cities are the two leaders which have been ranked as the ones with highest-level of on-line public service delivery [20]. However, there is not so much information on the fairness which is concerned with whether marginalized people are able to get 
access to the e-Government services. With more than $80 \%$ of Vietnamese population living in rural areas and a large number of 52 ethnic minorities, the inaccessability to the public services for all can be predicted. World Bank [23] also indicated that satisfaction of citizen to some certain public services are still lagging behind in several provinces.

Carrizales et al. suggest that e-Governance involves both the delivery of public service and citizen participation in government affairs [40]. Trust and Transparency, therefore, play an important role in this process. In our suggested conceptual framework for evaluating Vietnam's e-Government performance, the dimension of Trust and Transparency has also been found to be highly loaded on the public value-based e-Government conceptual framework [56]. There is a lack of research on the field to validate our judgments on the citizen's trust to e-Government services and by which the transparency of Vietnamese government affairs can be clarified. There are, however, several Vietnamese government's decrees, regulations relating to privacy and cyber security, and more involvement of citizen in the governance issued by either Vietnamese government or provincial authorities [18] [20] [57]. Given the nature of this dimension, there should be a plenty of area to be focused on by both Vietnamese policy makers, academicians, and citizens themselves.

\section{Limitations and Future Research}

Based on the data analysis and findings, a conceptual framework for evaluating Vietnam e-Government performance was empirically tested and proposed. The exploratory findings need to be considered tentatively. Yet, they are still interesting because there is a little empirical research which have explored this complex matter. The generalisability of this proposed conceptual framework, however, should be taken with due care. On the one hand, this research relies on purposive sampling rather than a more scientifically, suitable sample. On the other hand, the data are based on perceptions and attitudes of respondents rather than actual public value-based e-Government services which are diverse in its quantity and complex in its nature. The sampling composition and quantity need to be enlarged on a nation-wide scale in order to have a broader picture. Coupled with the ITC development in Vietnam over the past 4 consecutive years of from 2012 to 2015 as singled out by World Economic Forum [13]-[16], there is a plenty of room for future research in which confirmatory factor analysis can be adopted with the aim to confirm the validity of the latent and observed variables which are discussed in the proposed conceptual framework for evaluating Vietnam's e-Government performance based on the dimensions of public value. Once it is validated, more specific and meaningful issues of public value based e-Government services can be explored further. That is, each dimension of public value-based e-Government services should be understood at the levels of provincial authorities. Relationships among those very dimensions, or how they relate to the leadership in the field of e-Government performance can be clarified in future research either in a comparative setting or in the context of Vietnam [16] [56].

\section{References}

[1] ADB (2003) E-Government in the Asia and Pacific. The Governance in Brief, A Quarterly Publication Governance and Regional Cooperation Division Regional and Sustainable Development Department Issue 6-2003.

[2] ADB (2013) Empowerment and Public Service Delivery in Developing Asia. Policy Report.

[3] Kearns I. (2012) Public Value and E-Government.

[4] Karunasena, K. and Deng, H. (2012) A Citizen-Oriented Approach for Evaluating the Performance of E-Government in Sri Lanka. International Journal of E-Government Research, 8, 44-63. http://dx.doi.org/10.4018/jegr.2012010103

[5] Bend, J. (2004) Public Value and E-Health. Institute of Public Policy Research, London.

[6] Bai, W. (2013) A Public Value Based Framework for Evaluating the Performance of E-Government in China. Journal of iBusiness, 5, 26-29. http://dx.doi.org/10.4236/ib.2013.53b006

[7] eGEP (2006) Measurement Framework: Final Version, E-Government Economics Project. European Commission, Brussels.

[8] Alsaghier, H., Ford, M., Nguyen, A. and Hexel, R. (2009) Conceptualizing Citizen’s Trust in E-Government: Application of Q Methodology. Electronic Journal of E-Government, 7, 295-310.

[9] Heeks, R. (2008) Benchmarking E-Government: Improving the National and International Measurement Evaluation and Comparison of E-Government. In: Evaluation of Information Systems, Oxford, Butterworth-Heinemann. http://dx.doi.org/10.1016/b978-0-7506-8587-0.50017-2

[10] Karunasena, K. and Deng, H. (2009) A Conceptual Framework for Evaluating the Public Value of E-Government: A 
Case Study from Sri Lanka. Paper Presented at 20th Australasian Conference on Information Systems, 2-4 December 2009, Melbourne.

[11] UNDESA (2014) United Nations E-Government Survey: 2014 E-Government for the Future We Want. The Department of Economic and Social Affairs, United Nations, New York.

[12] Damuri, R. (2014) Services Sector Development and Improving Production Network in ASEAN. Economics Working Paper 01-2014, CSIS Working Paper Series.

[13] World Economic Forum (2015) The Global Information Technology Report 2015.

[14] World Economic Forum (2014) The Global Information Technology Report 2014.

[15] World Economic Forum (2013) The Global Information Technology Report 2013.

[16] World Economic Forum (2012) The Global Information Technology Report 2012.

[17] Khuong, V.M. (2014) ITC as a Source of Economic Growth in the Information Age: Empirical Evidence from the 1996-2005 Period. Accepted Paper Series, Lee Kuan Yew School of Public Policy, National University of Singapore, Singapore.

[18] GoV (2011) Decree No 43/2011/NĐ-CP on Provision of On-Line Information and Public Services in E-Websites or E-Portals of Public Organizations. June 13, 2011.

[19] Ministry of Information and Communication (2014) Decree No 25/TT/BTTTT/2014 on Regulations of Expanding ITC System from Central to Local Scales.

[20] Ministry of Information and Communication (2012) Report on Assessment of ITC Application among Ministries, Governmental Departments, and Industries, Provinces in 2012. http://cio.gov.vn/Portals/0/BCaoTTg130410_DGiaWebsiteUDCNTT2012_V3.pdf

[21] World Bank (2008) Accelerating Information \& Communication Technologies Development in Vietnam. Prepared by the Global ICT Department for the Vietnam Country Department.

[22] VCCI (2014) Information System of E-Government and Public Administration Reform to Enable the Favorable Business Environment in Danang. Proceedings of the E-Government Conference, Danang, 29 August 2014.

[23] World Bank (2015) Gauging Users' Satisfaction in Vietnam: Why, What and How? National Conference in Danang.

[24] Deng, H. (2012) Critical Factors for Evaluating the Public Value of E-Government in Sri-Lanka. Government Information Quarterly, 29, 74-84.

[25] Yang, Y. (2014) Studying of E-Government Affairs: The Foothold for the Popular Cultural Service in New Rural Area. Open Journal of Social Sciences, 2, 105-109. http://dx.doi.org/10.4236/jss.2014.211015

[26] Al-Shboul, M., Rababah, O., Al-Shboul, M., Ghnemat, R. and Al-Saqqa, S. (2014) Challenges and Factors Affecting the Implementation of E-Government in Jordan. Journal of Software Engineering and Applications, 7, 1111-1127. http://dx.doi.org/10.4236/jsea.2014.713098

[27] Bonina, C. and Cordella, A. (2008) The New Public Management, E-Government and the Notion of Public Value: Lessons from Mexico. Proceedings of the SIG GlobDev's First Annual Workshop, Paris, 13 December 2008.

[28] Castelnovo, W. and Simonetta, M. (2007) The Public Value Evaluation of E-Government Policies. The Electronic Journal of Information System Evaluation, 11, 61-72.

[29] UNDESA (2008) UN E-Government Survey 2008: From E-Government to Connected Governance. Department of Economic and Social Affairs, United Nations, New York.

[30] UNDESA (2003) World Public Sector Report 2003: E-Government at Cross Road-Global E-Government Survey. Department of Economic and Social Affairs, United Nations, New York.

[31] Ndou, V.D. (2004) E-Government for Developing Countries: Opportunities and Challenges. EJISDC, 18, 1-24.

[32] Golubeva, A.A. (2007) Evaluation of Regional Government Portals on the Basis of Public Value Concept: Case Study from Russian Federation. Proceedings of the 1st International Conference on Theory and Practice of Electronic Governance, Macao, 10-13 December 2007.

[33] Kim, S. (2009) A Case Study of Local E-Government Performance in South Korea: Do Leadership and Management for Results Matter? International Public Management Review, 10, 170-199. http://dx.doi.org/10.1108/s0732-1317(2009)0000018014

[34] Fan, Q. (2011) An Evaluation Analysis of E-Government Development by Local Authorities in Australia. International Journal of Public Administration, 34, 926-934. http://dx.doi.org/10.1080/01900692.2011.615550

[35] Nabafu, R. and Maiga, G. (2012) A Model of Success Factors for Implementing Local E-Government in Uganda. Electronic Journal of E-Government, 10, 31-46.

[36] Ank, M. (2012) Citizen Participation in Local Policy Making: Design and Democracy. International Journal of Public 
Administration, 35, 285-292. http://dx.doi.org/10.1080/01900692.2012.661301

[37] Basar, M. and Hande, K. (2014) Measuring the Correlation between Commercial and Economic States of Countries (B2G Relations) and the E-Government Readiness Index by Using Neural Networks. Open Journal of Business and Management, 2, 110-115. http://www.scirp.org/journal/ojbm

[38] Naz, R. (2009) E-Government for Improved Public Service Delivery in Fiji. Journal of Service Science and Management, 3, 190-203. http://dx.doi.org/10.4236/jssm.2009.23023

[39] Nudin, N., Stokdale, R. and Scheepers, H. (2012) Benchmarking Local E-Government in Indonesia. Proceedings of the PACIS Conference, Ho Chi Minh City, 14 July 2012, Paper No. 61.

[40] Carrizales, T., Melitski, J., Manoharan, A. and Holzer, M. (2011) E-Governance Approaches at the Local Level: A Case Study in Best Practice. International Journal of Public Administration, 34, 935-945. http://dx.doi.org/10.1080/01900692.2011.616988

[41] Welch, E., Hinnant, C. and Moon, C. (2005) Linking Citizen Satisfaction with E-Government and Trust in Government. Journal of Public Administration Research and Theory, 15, 371-391. http://dx.doi.org/10.1093/jopart/mui021

[42] Cole, M. and Parston, G. (2006) Unlocking Public Value: New Model for Achieving High Performance in Public Service Organization. Wiley \& Sons, Inc., Hoboken.

[43] Codagnone, C. and Undheim, T.A. (2008) Benchmarking E-Government: Tools Theory and Practice. European Journal of E-Practice, No. 4, 4-18.

[44] Gomez, J. and Sandoval, A.R. (2013) The Adoption of E-Government Services in Mexico: A Citizen’s Perception Analysis. American Journal of Industrial and Business Management, 3, 12-22. http://dx.doi.org/10.4236/ajibm.2013.36A002

[45] Ministry of Information and Communication (2007) Decree No 07/CT/BTTTT/2007 concerning the Take-Off Strategy for ITC Development in Vietnam in 2011-2020 Period.

[46] Moore, M.H. (1995) Creating Public Value: Strategic Management in Government. Harvard University Press, London.

[47] Wong, W. and Welch, E. (2004) Does E-Government Promote Accountability? A Comprehensive Analysis of Website Openness and Government Accountability. Governance: An International Journal of Policy Administration, and Institutions, 17, 275-297. http://dx.doi.org/10.1111/j.1468-0491.2004.00246.x

[48] Kumar, V., Mukerji, B., Butt, I. and Persaud, A. (2007) Factors for Successful E-Government Adoption: A Conceptual Framework. The Electronic Journal of E-Government, 5, 63-76.

[49] Sabri, A., Oma, S. and Bassam, A. (2013) A Cultural E-Government Readiness Model. Intelligent Information Management, 4, 212-216. http://www.SciRP.org/journal/iim

[50] Swierczek, W. and Ha, T.T. (2003) Entrepreneurial Orientation, Uncertainty Avoidance and Firm Performance. International Journal of Entrepreneurship and Innovation, 4, 46-58. http://dx.doi.org/10.5367/000000003101299393

[51] Douglas, S. and Craig, S. (1983) International Marketing Research. Prentice Hall, Englewood Cliffs.

[52] Hair Jr., J.F., Black, W.C., Babin, B.J. and Rolph, E. (2007) Multivariate Data Analysis. 7th Edition, Mc-Graw Hill Publishing House, New York.

[53] Gottchalk, P. and Solli-Saether, H. (2009) E-Government Interoperability and Information Resource Integration: Frameworks for Aligned Development. Information Science References, Hershey. http://dx.doi.org/10.4018/978-1-60566-648-8

[54] VNCI (2006) E-Government and Business Competitiveness: A Policy Review. Viet Nam Competitiveness Initiative (VNCI) Policy Paper No. 7.

[55] VNNews (2015) E-Gov’t Targets Increased Satisfaction. http://bizhub.vn/tech/6689/e-govt-targets-increased-satisfaction.html

[56] Scholl, H. and Kischewski, R. (2007) E-Government Integration and Interoperability: Framing Research Agenda. International Journal of Public Administration, 30, 889-920. http://dx.doi.org/10.1080/01900690701402668

[57] World Bank (2014) Taking Stock: An Update on Vietnam’s Recent Economic Developments. WB report 92825. 